R.V. Liutyi, M.V. Tyshkovets, D.V. Liuta, O.I. Sheiko

\title{
Physical and Chemical Fundamentals of Sodium Phosphate Use in Foundry Production
}

\author{
National Technical University of Ukraine "Igor Sikorsky Kyiv Polytechnic Institute”, Kyiv, Ukraine, \\ rvl2005@ukr.net,. maria15021996@gmail.com
}

\begin{abstract}
The technology of synthesis of inorganic binder material based on sodium tripolyphosphate $\mathrm{Na}_{5} \mathrm{P}_{3} \mathrm{O}_{10}$ and orthophosphoric acid has been developed. The technology involves pre-mixing of these components with subsequent exposure in the temperature range of $150 \ldots 200^{\circ} \mathrm{C}$. The sequence of physicochemical transformations in this system, as well as the optimal mass ratio of orthophosphoric acid and sodium tripolyphosphate are established.

The research uses methods of quantitative and qualitative X-ray phase analysis, differential thermal analysis, standard methods of testing samples for compressive strength. Phase analysis revealed that the material obtained as a result of chemical synthesis is mainly sodium pyrophosphate $\mathrm{Na}_{2} \mathrm{H}_{2} \mathrm{P}_{2} \mathrm{O}_{7}$, which has a number of valuable properties for use in technologies for the manufacture of molds and cores. The ratios of the atomic radii of the cation $(\mathrm{Na})$ and the anion $\left(\mathrm{P}_{2} \mathrm{O}_{7}\right)$, as well as the presence of hydrogen bonds, provide a significant increase in the binding potential compared to other sodium phosphates.

It was found that the strengthening of mixtures with $2 \ldots 8$ mass parts including sodium pyrophosphate, the filler of which is quartz-based sand, occurs as intensely as possible when heated to $150{ }^{\circ} \mathrm{C}$. A further increase in temperature above $250^{\circ} \mathrm{C}$ leads to the conversion of sodium pyrophosphate to ordinary (non-polymeric) metaphosphate $\mathrm{NaPO}_{3}$, which exists without changes in chemical structure up to $1000{ }^{\circ} \mathrm{C}$. Molds and cores with developed binder material have adequate thermal and chemical resistance to molten steel and cast iron. This has been proven experimentally.

The developed binder, given the global trends of decarbonization and resource conservation, is a competitive alternative to widely used synthetic resins and other organic materials. It does not contain harmful substances and does not emit dangerous products when heated.

Key words: binder, core mixture, compressive strength, ionic radius, orthophosphoric acid, sodium pyrophosphate, sodium tripolyphosphate.
\end{abstract}

Received 12 November 2020; Accepted 15 December 2020.

\section{Introduction}

Phosphates are inorganic salts of ortho- $\left(\mathrm{H}_{3} \mathrm{PO}_{4}\right)$, pyro- $\left(\mathrm{H}_{4} \mathrm{P}_{2} \mathrm{O}_{7}\right)$, metaphosphoric $\left(\mathrm{HPO}_{3}\right)$ and polyacidstripolyphosphate $\mathrm{H}_{5} \mathrm{P}_{3} \mathrm{O}_{10}$ and hexametaphosphate $\mathrm{H}_{6} \mathrm{P}_{4} \mathrm{O}_{13}$. In essence, all of these acids are polymorphic species. They turn into each other under certain thermal conditions. Their salts behave in the same way [1].

Phosphate-based materials occupy leading positions in terms of use in various fields of technology. This is due to their availability, prevalence, simplicity of production methods. Phosphorus is an essential element for all living organisms on planet Earth. Phosphate materials are widely used: mineral fertilizers $(90 \%$ of the total volume), food additives (orthophosphoric acid is registered as an additive E338, sodium tripolyphosphate $\mathrm{Na}_{5} \mathrm{P}_{3} \mathrm{O}_{10}-\mathrm{E} 451$, sodium metaphosphate $\left(\mathrm{NaPO}_{3}\right)_{\mathrm{n}}-$ $\mathrm{E} 452$, therapeutic and prophylactic industry, refractory paints, active components in industrial and household detergents (water softener) [1-6].

An important feature of phosphates is the binding ability, which is manifested in combination with various materials. The ability to adhesion and bind is inherent in many inorganic salts, but phosphates have a leading place among them $[1,2,7]$. This feature is due to their 
crystalline structure, which in turn is due to the position of phosphorus in the periodic table. Phosphorus as an element of group IV has a d-p bond in the tetrahedron PO4 at the maximum number of d-orbitals [8].

Sodium tripolyphosphate is part of most dishwashing detergents and dishwashers and passes through state-ofthe-art treatment systems and enters open water bodies, where it acts as a mineral fertilizer. This leads to rapid flowering of plants, and then - to the aging of lakes, rivers and seas [3, 4]. 1 gram of sodium tripolyphosphate causes the growth of $5 \ldots 10 \mathrm{~kg}$ of cyanobacteria, as a result of which the oxygen content in the water decreases, toxic substances are formed, which leads to mass death of hydro fauna. Fresh water becomes unfit for drinking and life-threatening [6]. In addition, thousands of tons of sodium tripolyphosphate enter the sea annually [5].

In Denmark, $54 \%$ of detergents do not contain phosphates, and in Belgium - more than $80 \%$. Austria, Germany, Italy, the Netherlands, Norway, Switzerland, Korea, Hong Kong, Thailand, South Africa, and several US states have banned the use of phosphates in washing powders; in Japan, phosphates from powders disappeared in the mid-1980s [3].

This is a global problem of world ecology, but today in Ukraine the use of sodium polyphosphates is very significant. Obviously, the solution to environmental problems is to remove phosphates from household chemicals. It is not possible to stop their production altogether, as they are by-products of the synthesis of phosphoric acids and mineral fertilizers, and their annual amount will not decrease significantly in the coming years.

The question of finding new areas of application of significant amounts of sodium phosphates is acute. In our opinion, a closed-loop technology industry can be effective in preventing or reducing the entry of hazardous materials into the ecosystem. An example of such an industry is foundry production, in which other phosphates are already used.

As is known [9-11], phosphates of metals of groups I and II of the periodic table can either not be obtained synthetically or do not have a binding capacity. However, polymeric phosphates, such as sodium tripolyphosphate $\left(\mathrm{Na}_{5} \mathrm{P}_{3} \mathrm{O}_{10}\right)$, have a binding capacity.

Today, in the foundry industry, they are not considered as binder for molding and core mixtures. However, sodium tripolyphosphate is used as a binder for non-stick coatings [12-14]. It or sodium hexametaphosphate $\mathrm{Na}_{6} \mathrm{P}_{6} \mathrm{O}_{18}$ in the amount of $0.5 \ldots 1.5 \mathrm{wt} . \%$ is used as a technological admixture to sand-bentonite suspensions to reduce their viscosity, which reduces the consumption of bentonite clay in the molding mixtures $[14,15]$.

Some attempts to use sodium polyphosphate as a binder in the core mixture are reflected in patents [16, 17], for refractory concrete - in [18].

\section{The Aim of the Research}

The aim of our research is to develop a technology for the synthesis of sodium phosphate binder with a high level of strength and thermal stability for the needs of foundry production and the study of its composition, structure and properties.

Research objectives:

1. Investigate the patterns of chemical interaction of sodium tripolyphosphate with orthophosphoric acid.

2. Investigate the phase composition and scheme of thermal transformations of binder synthesized from sodium tripolyphosphate and orthophosphoric acid.

3. Investigate the physical and mechanical properties of molding and core mixtures with a binder synthesized with sodium tripolyphosphate and orthophosphoric acid.

4. Establish the possibility of making castings using synthesized binder.

\section{Research Methods}

A number of physicochemical methods for studying the structure and properties of materials are used in the work.

$\mathrm{X}$-ray phase qualitative and quantitative analysis was performed on the installation "Rigaku Ultima IV".

Differential thermal analysis was performed on the installation "STA 449 C Jupiter".

Orthophosphoric acid of $85 \%$ concentration was used. In addition to acid, the material for research is sodium tripolyphosphate, the structural formula of which is shown in Fig. 1.

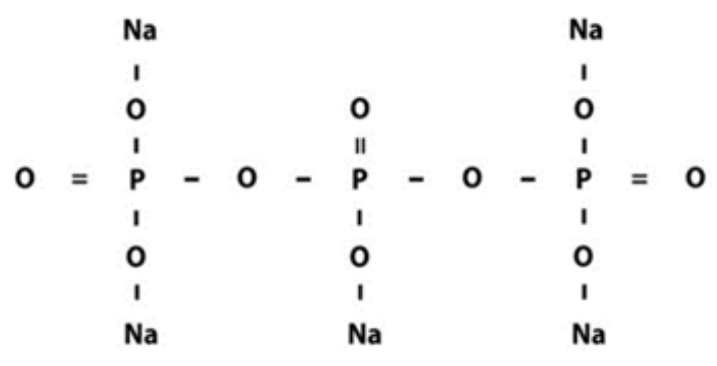

Fig.1. Structural formula of sodium tripolyphosphate.

The strength of the molding and core mixtures were determined using standard techniques common in standard cylindrical samples with a diameter and a height of $50 \mathrm{~mm}$.

Production of molds, cores, melting and pouring of alloy steel was carried out in the foundry laboratory of Igor Sikorsky Kyiv Polytechnic Institute.

\section{Results and Discussions}

The authors [1, 11] confirmed that the binding capacity of inorganic salts is determined by the following characteristics:

- the magnitude of the radius of the cation that is part of the salt, and its ionic potential (Table 1);

- the ratio of the radii of the cation and the anion (the anion is the ion of orthophosphoric acid $\mathrm{PO}_{4}{ }^{3-}$ );

- the coordination number of the cation.

The optimal ratio of ionic radii is considered to be $0.12 \ldots 0.25$. Therefore, the strongest phosphate binders 
Table 1

Atomic crystalline characteristics of phosphates

\begin{tabular}{|c|c|c|c|c|c|}
\hline Cation & $\begin{array}{c}\text { Ionic } \\
\text { radius } r_{k}, \mathrm{~nm}\end{array}$ & $\begin{array}{l}\text { The strength of } \\
\text { the cation field, } \\
\qquad \frac{n_{e}}{r_{k}^{2}}\end{array}$ & $\begin{array}{c}\frac{r_{k}}{r_{a}} \\
\left(\text { anion }-\mathrm{PO}_{4}^{3-}\right)\end{array}$ & $\begin{array}{c}\frac{r_{k}}{r_{a}} \\
\left(\text { anion }-\mathrm{P}_{4} \mathrm{O}_{7}^{4-}\right)\end{array}$ & $\begin{array}{c}\text { Coordination } \\
\text { number of the } \\
\text { cation }\end{array}$ \\
\hline 1 & 2 & 3 & 4 & 5 & 6 \\
\hline \multicolumn{6}{|c|}{ Literature data [11] } \\
\hline $\mathrm{B}^{3+}$ & 0.025 & 17.24 & 0.08 & - & 4 \\
\hline $\mathrm{Al}^{3+}$ & 0.057 & 9.23 & 0.19 & - & 4,6 \\
\hline $\mathrm{Cr}^{3+}$ & 0.064 & 7.30 & 0.21 & - & 6 \\
\hline $\mathrm{Fe}^{3+}$ & 0.067 & 6.68 & 0.22 & - & $4,6,8$ \\
\hline $\mathrm{Mg}^{2+}$ & 0.074 & 3.65 & 0.24 & - & $4,6,8$ \\
\hline $\mathrm{Zn}^{2+}$ & 0.083 & 1.92 & 0.27 & - & 4 \\
\hline \multicolumn{5}{|c|}{ The results of calculations } & \\
\hline $\mathrm{K}^{+}$ & 0.133 & 0.57 & 0.44 & 0.270 & 4 \\
\hline $\mathbf{N a}^{+}$ & 0.098 & 1.04 & 0.33 & 0.196 & 4 \\
\hline $\mathrm{Ca}^{2+}$ & 0.106 & 1.78 & 0.35 & 0.210 & $4,6,8$ \\
\hline $\mathrm{Zr}^{4+}$ & 0.082 & 5.95 & 0.27 & 0.160 & 8 \\
\hline $\mathrm{Si}^{4+}$ & 0.039 & 26.30 & 0.13 & 0.080 & 4 \\
\hline
\end{tabular}

are formed using divalent cations, which have dimensions of $0.07 \ldots 0.08 \mathrm{~nm}[1,11]$.

The authors [11] also presented the calculations of these characteristics for elements from B to $\mathrm{Zn}$ (Table 1). This table is supplemented by our own calculations of similar indicators for phosphates $\mathrm{K}, \mathrm{Ca}, \mathrm{Si}, \mathrm{Zr}$ and especially Na (column 4 of Table 1). This choice is due to positive data previously obtained from the synthesis of $\mathrm{Si}$ and $\mathrm{Zr}$ phosphates in core mixtures [19-22].

The calculations showed that only silicon phosphate has atomic-crystalline parameters within the recommended limits. For other elements, the ratio of ionic radii exceeds 0.25 , and this is one of the reasons why they are not considered as a potential basis for the synthesis of binder.

Previous researches [19-22] found that mixtures of orthophosphoric acid with quartz or zircon fillers do not form orthophosphates, but pyrophosphates of these elements. This is due to the fact that the chemical interaction that leads to the formation of these compounds is carried out by heating. If this heating is above $200{ }^{\circ} \mathrm{C}$, orthophosphoric acid $\mathrm{H}_{3} \mathrm{PO}_{4}$ in the mixture is converted into pyrophosphoric $\mathrm{H}_{4} \mathrm{P}_{2} \mathrm{O}_{7}$.

The pyrophosphoric acid anion (Fig. 2,b) has similar elements to the orthophosphoric acid anion (Fig. 2,a). Large spheres in the diagram indicate oxygen atoms, small - phosphorus atoms.

According to the scheme, it can be determined that the pyrophosphate ion has a radius of about $0.50 \mathrm{~nm}$. Then the ratio $\mathrm{r}_{\mathrm{k}} / \mathrm{r}_{\mathrm{a}}$ for phosphates will change (column 5 of Table 1), and for sodium pyrophosphate will be 0.196 . This value falls within the recommended limits $(0.12 \ldots 0.25)$ for maximum realization of the binding potential. Thus, for sodium, the preferred form of binder is pyrophosphate.

Thus, we can conclude that the formation of phosphates of monovalent metals, calcium, as well as $\mathrm{Si}$ and $\mathrm{Zr}$ is a promising direction for obtaining fundamentally new inorganic binders for core mixtures.
The formation of their properties is fully consistent with existing scientific ideas.

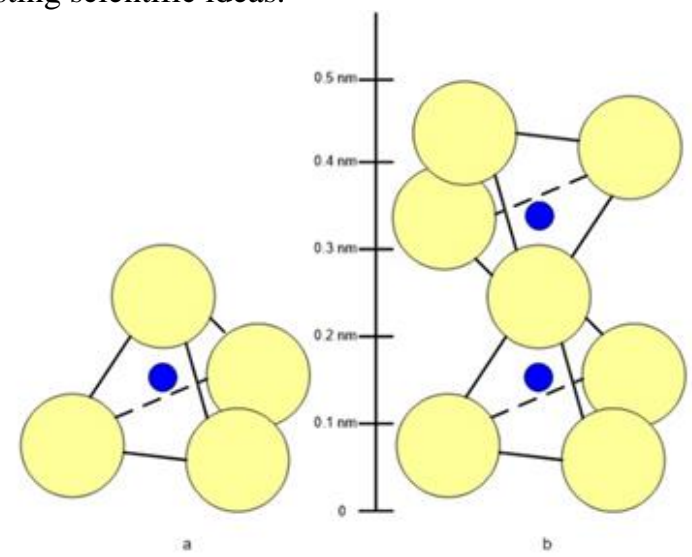

Fig. 2. The structure of the anions of ortho- and pyrophosphoric acids: a - phosphate ion $\mathrm{PO}_{4}{ }^{3-}$; $\mathrm{b}$ - pyrophosphate ion $\mathrm{P}_{2} \mathrm{O}_{7}{ }^{4}$.

According to D. Kingery, acidic phosphates have a greater binding capacity [23]. Monographs [2, 7, 10] explain the special role of hydrogen bonding in the manifestation of the properties of inorganic cements. Therefore, the formation of hydro phosphates is a priority.

During the studies, mixed in different mass ratios of sodium tripolyphosphate with orthophosphoric acid, kept for 1 hour at a temperature of $150 \ldots 200^{\circ} \mathrm{C}$. After heat treatment, the samples were cooled and ground to a fraction of not more than $0.2 \mathrm{~mm}$.

The obtained weights were used for the manufacture of standard samples of molding and core mixtures for strength testing. In addition, sodium tripolyphosphate was used in its original form. River quartz sand $3 \mathrm{~K}_{5} \mathrm{O}_{3} 025$ was used as a filler for the mixture. Samples of the mixtures were dried for 1 hour at a temperature of $200{ }^{\circ} \mathrm{C}$. The results of compressive strength control are 
shown in Fig. 3.

As can be seen, the mixture in which sodium tripolyphosphate is used as a separate binder (without acid) has a strength of 2.5 ...3.0 times less than with acid (Fig. 3).

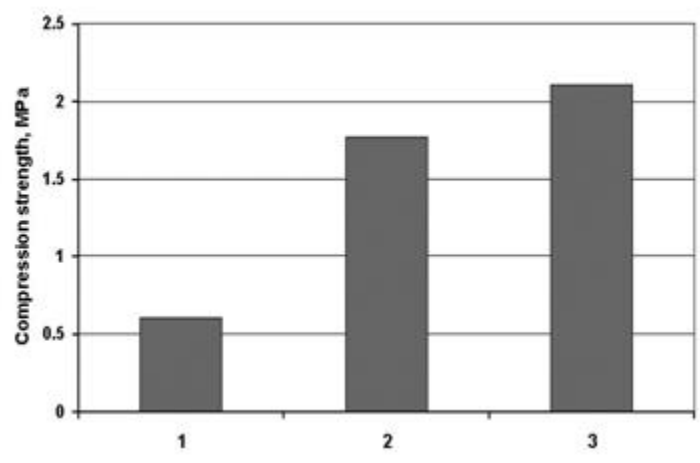

Fig. 3. Compressive strength of sodium tripolyphosphate mixtures: 1 - samples with 5.0 mass parts sodium tripolyphosphate; $2-$ samples with 3.0 mass parts sodium tripolyphosphate and 3.0 mass parts $\mathrm{H}_{3} \mathrm{PO}_{4} ; 3$ samples with 5.0 mass parts pre-mixed and heated to a temperature of $200{ }^{\circ} \mathrm{C}$ composition (5.0 mass parts $\mathrm{Na}_{5} \mathrm{P}_{3} \mathrm{O}_{10}+1.0$ mass part $\mathrm{H}_{3} \mathrm{PO}_{4}$ ).

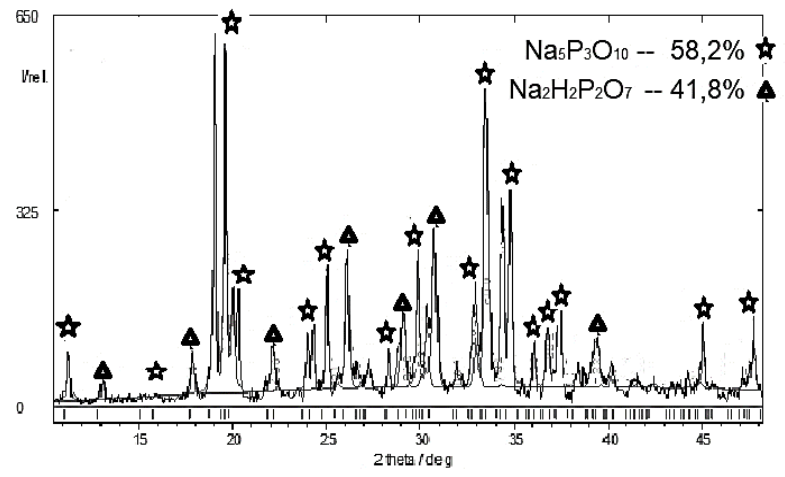

Fig. 4. Phase analysis of the composition (5.0 mass parts $\mathrm{Na}_{5} \mathrm{P}_{3} \mathrm{O}_{10}+1.0$ mass part $\mathrm{H}_{3} \mathrm{PO}_{4}$ ), heat treated at a temperature of $200{ }^{\circ} \mathrm{C}$.
When combining orthophosphoric acid with sodium tripolyphosphate, transformation is especially important from a scientific and technological point of view. This effect of a significant increase in strength is explained by the fact that heating this composition does not increase the degree of polymerization of sodium tripolyphosphate, as we assumed earlier [24], but to a full chemical interaction between them, resulting in the formation of disubstituted sodium pyrophosphate:

$$
2 \mathrm{Na}_{5} \mathrm{P}_{3} \mathrm{O}_{10}+4 \mathrm{H}_{3} \mathrm{PO}_{4} \stackrel{150 . \ldots 200^{\circ} \mathrm{C}}{\longrightarrow} 5 \mathrm{Na}_{2} \mathrm{H}_{2} \mathrm{P}_{2} \mathrm{O}_{7}+\mathrm{H}_{2} \mathrm{O}
$$

X-ray phase analysis confirmed the formation of pyrophosphate (Fig. 4). It has all the necessary structural features (the ratio of the radii of the cation to the anion is 0.196 , as well as the presence of additional hydrogen bonds). That is why this pyrophosphate provides the effect of significant strengthening of the mixture.

For complete reaction (1), taking into account the acid concentration (85\%), the mass ratio of $\mathrm{Na}_{5} \mathrm{P}_{3} \mathrm{O}_{10}: \mathrm{H}_{3} \mathrm{PO}_{4}$ should be 1.6:1. However, it has been found that when mixed with an acid less than 3.0 mass parts of $\mathrm{Na}_{5} \mathrm{P}_{3} \mathrm{O}_{10}$, significant technological difficulties arise due to the increased viscosity of the composition and the difficulty of grinding it after heat treatment to the required fraction. As a result, the process is actually carried out with an excess of sodium tripolyphosphate. The choice of the composition for phase and thermal analysis is explained by the fact that the maximum strength has samples with a mass ratio of 5:1 (Fig. 5).

It is established that in terms of molar masses, instead of 736 mass parts, only 236 reacted, ie 500 remained. Under this condition, 355 mass parts of sodium pyrophosphate should be formed instead of 1110 by reaction (1). The estimated mass composition of the sample is $41.5 \%$ pyrophosphate (355 mass parts) and $58.5 \%$ (500 mass parts) of residual sodium tripolyphosphate. This ratio is established with high accuracy by experimental phase analysis (Fig. 4).

A study of the behavior of this composition when heated to $1000{ }^{\circ} \mathrm{C}$. For this purpose, differential

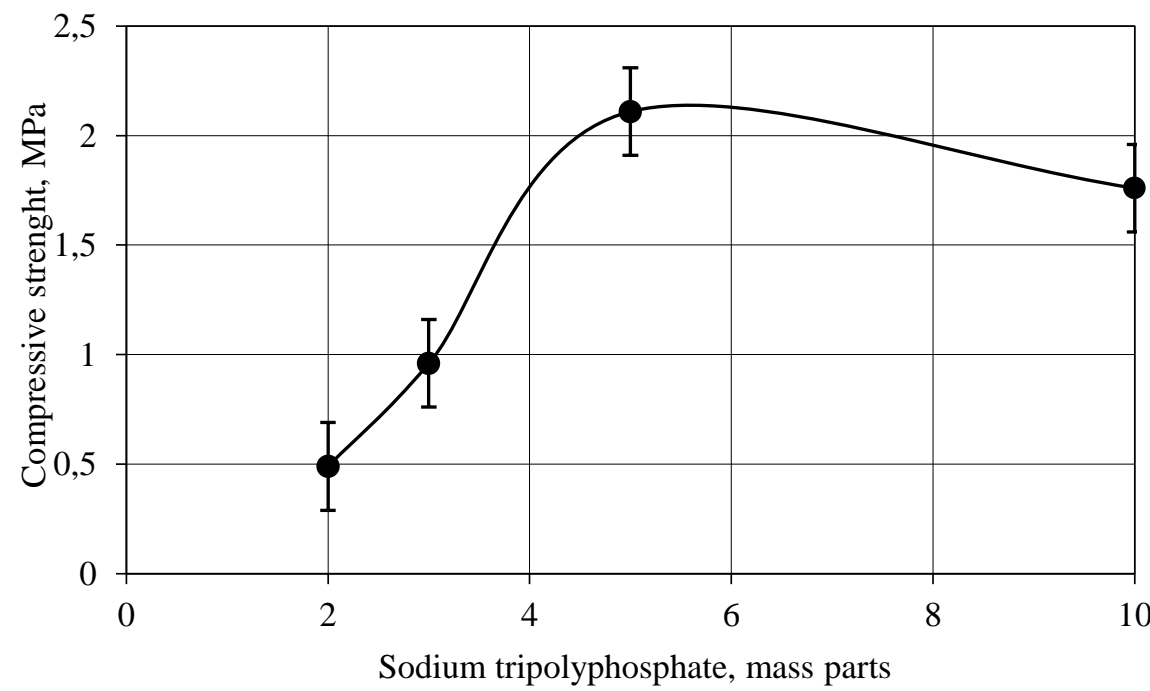

Fig. 5. The dependence of the strength of the mixture on the ratio of sodium tripolyphosphate and acid (1.0 mass part). 
thermogravimetric analysis was performed. It showed that in general the synthesized binder, which consists of sodium tripolyphosphate and sodium pyrophosphate, is characterized by thermal stability (Fig. 6).

Several endothermic effects were identified that require additional analysis and explanation. Data of the authors [25-33] regarding the properties of sodium phosphates when heated are contradictory, but it is possible to establish general patterns.

The authors [25] found on the heating curves of a mixture of sodium tripolyphosphate with sodium dihydrogen phosphate $\mathrm{Na}_{2} \mathrm{HPO}_{4} \cdot \mathrm{nH}_{2} \mathrm{O}$, that at $180{ }^{\circ} \mathrm{C}$ is the cleavage of crystal hydrate water from sodium dihydrogen phosphate, at a temperature of $245^{\circ} \mathrm{C}$ from this salt is removed structural water, and when heated to $300 \ldots 370{ }^{\circ} \mathrm{C}$ it decomposes. Similar endothermic effects associated with polymorphic transformations of $\mathrm{Na}_{4} \mathrm{P}_{2} \mathrm{O}_{7}$ have been identified in the thermal analysis curve [26].

Our researches have shown that the beginning of the first endothermic effect on the differential thermogravimetric analysis curve of the experimental sample is close to $250^{\circ} \mathrm{C}$, but in our case instead of $\mathrm{Na}_{2} \mathrm{HPO}_{4} \cdot \mathrm{nH}_{2} \mathrm{O}$ dihydrogen phosphate there is acidic $\mathrm{Na}_{2} \mathrm{H}_{2} \mathrm{P}_{2} \mathrm{O}_{7}$ pyrophosphate. According to [27], in the temperature range of $220 \ldots 250{ }^{\circ} \mathrm{C}$ should be its transformation according to the following scheme:

$$
\mathrm{Na}_{2} \mathrm{H}_{2} \mathrm{P}_{2} \mathrm{O}_{7} \stackrel{220 \ldots 250^{\circ} \mathrm{C}}{\longrightarrow} 2 \mathrm{NaPO}_{3}+\mathrm{H}_{2} \mathrm{O}
$$

Calculations have shown that, according to reaction (2), the weight loss in the form of water vapor should be $8.1 \%$. Given the content of pyrophosphate in the sample (41.8\%), the estimated weight loss will be $3.4 \%$, and the curve of thermal analysis (Fig. 6), this figure is $3.7 \%$, which almost coincides with the theoretical. Thus, it can be stated that sodium metaphosphate was formed in the sample, the form of which is also important for further analysis.
The endothermic effect on the thermal analysis curve of sodium tripolyphosphate at a temperature of $510 \ldots 520^{\circ} \mathrm{C}$, according to the authors $[25,28]$, corresponds to the polymorphic conversion of $\mathrm{Na}_{5} \mathrm{P}_{3} \mathrm{O}_{10}$ (II) to $\mathrm{Na}_{5} \mathrm{P}_{3} \mathrm{O}_{10}$ (I). Compound (I) form in the studied temperature range does not give endothermic effects [28].

During the research we found a similar endothermic effect at a temperature of $521.1^{\circ} \mathrm{C}$. Based on this, we can conclude that the sodium tripolyphosphate we used to have the configuration (II), and it was transformed into form (I).

Sodium phosphates are mostly not characterized by high thermal stability. From the literature it is known that the melting point is: sodium tripolyphosphate $-622^{\circ} \mathrm{C}$, sodium hexametaphosphate $-408{ }^{\circ} \mathrm{C}$, pyrophosphate $\mathrm{Na}_{4} \mathrm{P}_{2} \mathrm{O}_{7}-890{ }^{\circ} \mathrm{C}$, sodium orthophosphate $\mathrm{Na}_{3} \mathrm{PO}_{4}-$ $1340{ }^{\circ} \mathrm{C}[29,30]$.

We believe that in the sample that was investigated, could be formed as a simple metaphosphate $\left(\mathrm{NaPO}_{3}\right)_{\mathrm{n}}$ and sodium hexametaphosphate. They differ in melting point by almost $200^{\circ} \mathrm{C}$.

It is known that on the curve of thermal analysis of amorphous $\left(\mathrm{NaPO}_{3}\right)_{\mathrm{n}}$ obtained by dissolution and subsequent rapid cooling, there is an exothermic effect associated with the usual transition of this metaphosphate to the crystalline state at a temperature of about $400{ }^{\circ} \mathrm{C}$. The endothermic effect, which is observed at a temperature of about $580{ }^{\circ} \mathrm{C}$, corresponds to the melting process [31, 32]. The authors [33] isolated a similar endothermic effect at a temperature of $630{ }^{\circ} \mathrm{C}$ along the thermal analysis curve $\left(\mathrm{NaPO}_{3}\right)_{\mathrm{n}}$. After that, when heated to $1100{ }^{\circ} \mathrm{C}$, the weight loss should be very small $(0.4 \%)$, as confirmed by our experiment.

Based on own research, it was found that the thermal analysis curve (Fig. 6) shows a double endothermic effect, the first part of which is closer to $520^{\circ} \mathrm{C}$, ie polymorphic transformation of sodium tripolyphosphate, and the second - around $580^{\circ} \mathrm{C}$, which obviously

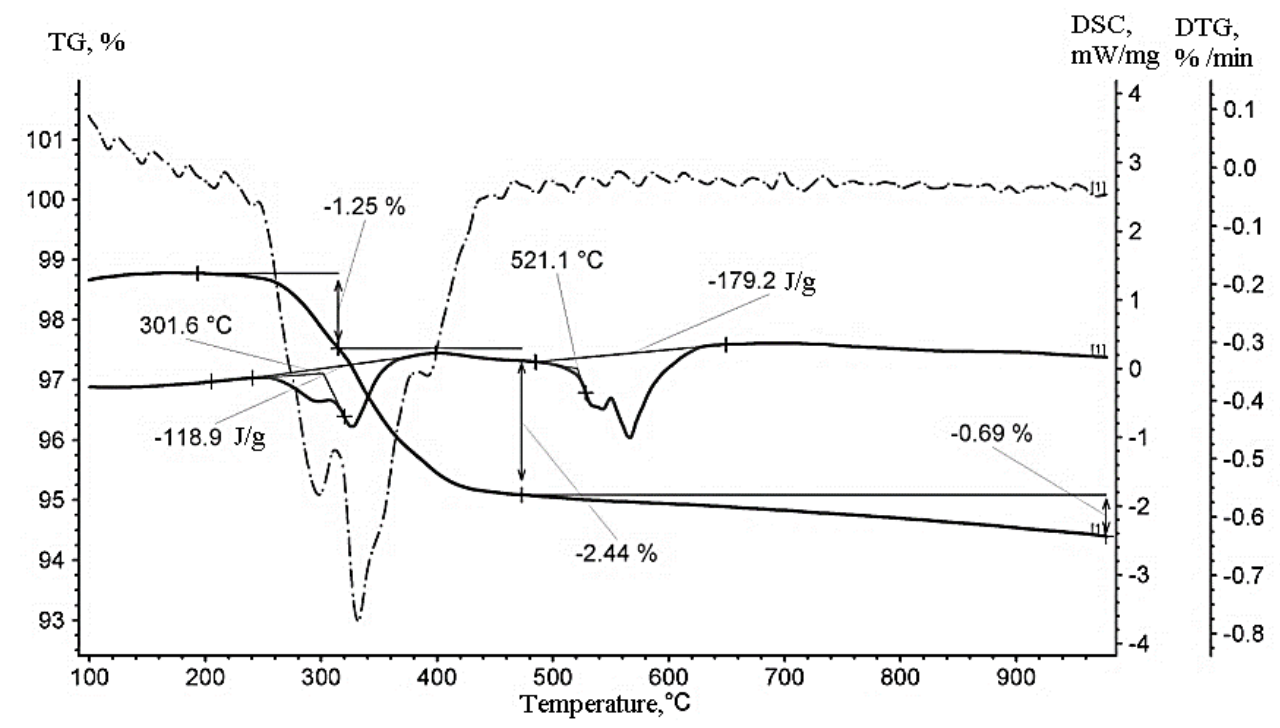

Fig. 6. Differential thermogravimetric analysis of the composition (5.0 mass parts $\mathrm{Na}_{5} \mathrm{P}_{3} \mathrm{O}_{10}++1.0$ mass part $\left.\mathrm{H}_{3} \mathrm{PO}_{4}\right)$, heat treated at a temperature of $200{ }^{\circ} \mathrm{C}$. 
corresponds to the melting of metaphosphate. Since pyrophosphate is already absent in the sample (it was converted by reaction (2)), at a temperature of $890{ }^{\circ} \mathrm{C}$ there is logically no endothermic effect associated with its melting.

Other physicochemical processes and those that can adversely affect the quality of castings (release of gaseous phases, decomposition of phosphates), have not been identified in the course of research.

In the manufacture of foundry cores, which are strengthened by heating, important from an economic point of view, is the temperature of the equipment. Based on the research, the composition of the molding and core mixture is proposed, which contains a refractory filler, created binder and water. The main purpose of water in the mixture is the formation of a solution of binder and ensuring its adhesion to the filler particles. The mixture is strengthened by dehydration of binder (water removal) during drying. At the same time binder, standing out from a solution, forms a strong framework from the hardened films.

During the research found that the mixture can be strengthened and at normal temperature, but the process is very long (over 24 hours). Heating accelerates the evaporation of water. The maximum strength of the core mixture (more than $2.5 \mathrm{MPa}$ ) is achieved after drying at a temperature of $150{ }^{\circ} \mathrm{C}$ (Table 2).

The strength of mixtures with created binder at its mass parts.

Based on the research, the optimal composition of the molding and core mixture is proposed, which includes: binder (5.0 mass parts $\mathrm{Na}_{5} \mathrm{P}_{3} \mathrm{O}_{10}+1.0$ mass part $\left.\mathrm{H}_{3} \mathrm{PO}_{4}\right)-3.0 \ldots 4.0$ mass parts, water -3.0 mass parts, quartz sand - the rest. Drying temperature $-150^{\circ} \mathrm{C}$. It has been established that foundry molds and cores, including the first class of complexity, can be made from this mixture.

From the mixture of the specified composition made half (lower) of the mold for the control casting "Dog" (Fig. 7,a). The half-form was dried at a temperature of $150{ }^{\circ} \mathrm{C}$ for 1 hour. The second (upper) half of the mold was made of green loam-sand mixture to compare the quality of cast surfaces. The form was filled with heatresistant steel $(0.2 \% \mathrm{C}, 25.0 \% \mathrm{Cr}, 2.0 \% \mathrm{Al}, 0.2 \% \mathrm{Ti})$ at a temperature of $1560{ }^{\circ} \mathrm{C}$.

The casting is obtained without defects caused by interaction with the mold: no burning-on and other defects. The quality of the cast surface is better than the surface of the loam-sand half-form. The obtained result indicates the absence of physicochemical interaction of the components of the developed mixture with the molten metal.

For the production of castings "Nozzle burner of thermal power plant unit" (Fig. 7, b) from the same steel used cores from the created mixture. The cores are made in equipment heated to $150{ }^{\circ} \mathrm{C}$.

Table 2

Compressive strength of the samples of the core mixture depending on the temperature

\begin{tabular}{|c|c|c|c|c|}
\hline Temperature $^{\circ} \mathrm{C}$ & 100 & 150 & 200 & 250 \\
\hline Compressive strength, $\mathrm{MPa}$ & 1.61 & 2.73 & 2.11 & 2.09 \\
\hline
\end{tabular}

Table 3

Compressive strength of the samples of the core mixture depending on the content of binder

\begin{tabular}{|c|c|c|c|c|c|c|c|}
\hline The content of binder, $\%$ & 2.0 & 3.0 & 4.0 & 5.0 & 6.0 & 7.0 & 8.0 \\
\hline Compressive strength, $\mathrm{MPa}$ & 2.35 & 2.90 & 3.10 & 3.25 & 3.35 & 3.45 & 3.60 \\
\hline
\end{tabular}

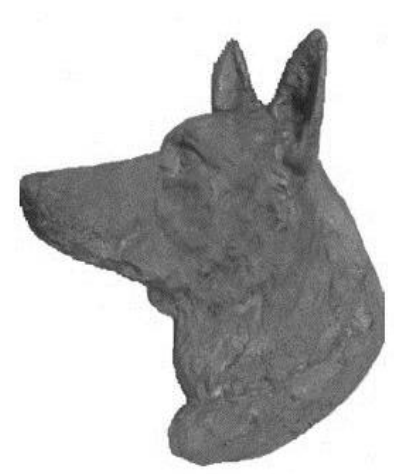

a

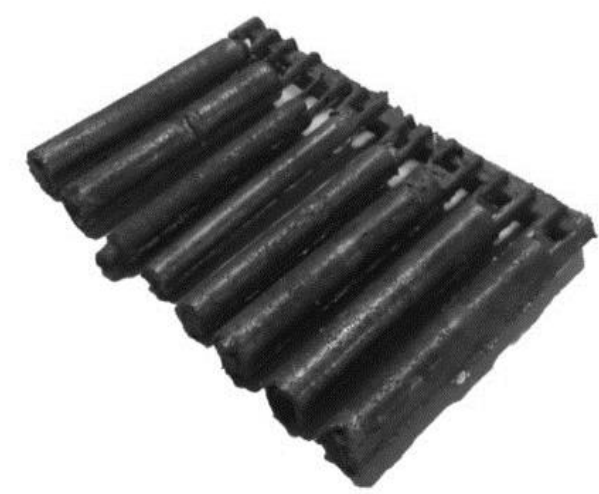

b

Fig. 7. Casting made using molds and cores of created binder.

content of 2.0..3.0 mass parts reaches high values 2.3..2.5 MPa (Table 3). At a content of 4.0 mass parts binder, the strength indicators become stable and almost do not increase with its subsequent addition. Therefore, the optimal content of binder in the mixture is $3.0 \ldots 4.0$
The cores fully provided the castings of the proper configuration. After cooling, the core was removed from the internal cavities of the castings without effort. The inner cast surface has no burning-on or other defects.

Thus, the mixture with binder, created on the basis of 
sodium tripolyphosphate and orthophosphoric acid, is fully suitable for the technology of foundry production.

\section{Conclusions}

1. The peculiarities of structure formation in the composition of sodium tripolyphosphate with orthophosphoric acid have been studied. Established that their interaction at about $200{ }^{\circ} \mathrm{C}$ leads to the formation of a new compound - disubstituted sodium pyro-phosphate $\mathrm{Na}_{2} \mathrm{H}_{2} \mathrm{P}_{2} \mathrm{O}_{7}$, which has additional hydrogen bonds, resulting in increasing adhesion to refractory filler and provides a significant increase in strength molding and core mixtures compared to sodium tripolyphosphate.

2. The phase composition and thermal transformations of the binder formed during the chemical interaction of sodium tripolyphosphate with orthophosphoric acid have been studied. It is established that due to the technological features of the process of chemical synthesis, the binder consists of approximately equal mass amounts of sodium tripolyphosphate and disubstituted sodium pyrophosphate. It is determined that pyrophosphate is converted to sodium metaphosphate upon heating, followed by melting of sodium metaphosphate. The release of gaseous substances and the decomposition of phosphates does not occur.

3. Designed binding component based on sodium tripolyphosphate and orthophosphoric acid provides high strength and thermal stability of molds and cores and enables to produce castings with clean surfaces with different alloys, including alloy steel.

4. The optimal composition of the molding and core mixture with created binder has been developed. Laboratory tests have shown the prospects for the use of molding and core mixtures, which provide high quality castings.

5. The use of the created binder makes it possible to use sodium tripolyphosphate in foundry production for the preparation of molding and core mixtures. This allows in the technological process of making castings to dispose of harmful product and contribute to the preservation of the ecological environment.

Liutyi R. - Candidate of Technical Sciences, Assistant Professor, Department of Foundry Productions of Ferrous and Non-Ferrous Metals;

Tyskovets M. - Postgraduate student of the Department of Foundry Productions of Ferrous and Non-Ferrous Metals;

Liuta D. - Candidate of Technical Sciences;

Sheiko O. - Candidate of Technical Sciences, Assistant Professor, Department of Foundry Productions of Ferrous and Non-Ferrous Metals.

[1] L.G. Sudacas, Phosphate binding systems (RIA «Kvintet», St. Petersburg, 2008).

[2] V.A. Kopeykin, A.P. Petrova, I.L. Rashkovan, Phosphate-based materials (Moscow, Khimiya, 1976) (https://doi.org/10.1016/j.mspro.2015.11.116).

[3] Web source: http://ecolog-ua.com/news/ukrayina-i-fosfaty-shcho-nas-vbyvaye.

[4] Ye.M. Kryzhanovs'kyy, Collection of scientific articles "III All-Ukrainian Congress of Ecologists with International Participation" (Vinnytsia, 2011). P. 216.

[5] V.I. Dubovyy, O.V. Dubovyy, Ecological culture: a textbook (Kherson, Hrin' D.S., 2016).

[6] V.Ye. Pochaps'kyy, S.O. Osypenko, Proceedings of the International Scientific and Practical Conference "Environmental Problems of the Environment and Environmental Management in the Context of Sustainable Development" (Poltava, 2019). P. 90.

[7] M.M Sychev, Inorganic adhesives (Leningrad, Khimiya, 1974).

[8] Yu.M. Butt, V.Ye. Kaushanskiy, Inorganic materials (1973).

[9] J.D. Wygant, Ceramic production processes (Moscow, Inlit, 1960).

[10] V.A. Kopeykin, V.S. Klement'yeva, B.L. Krasnyy, Refractory solutions on phosphate binders (Moscow, Metallurgiya, 1986).

[11] V.I. Fokin, N.V. Bagrova, G.P. Korolev, D.F. Bagrov, Foundry production 9, 17 (1998).

[12] S.P. Doroshenko, V.P. Avdokushyn, K. Rusyn, I. Matsashek, Molding materials and mixtures (Kyiv, Vyshcha shkola, 1980).

[13] S.P. Doroshenko, Molding mixtures (Kyiv, IZMN, 1997).

[14] A.N. Boldin, N.I. Davydov, S.S. Zhukovskiy and other, Foundry molding materials. Molding, core mixtures and coatings (Moscow, Mashinostroyeniye, 2006).

[15] E.I. Sych, New technological processes of foundry (Moscow, 1967).

[16] Makiguchi Toshisada, Muramatsu Akira, Kurabe Hyojir, Patent US 4078599 A (14 March1978).

[17] Kawasaki Heavy IND LTD, Patent GB 1192633 A (20 May 1970).

[18] A.P. Baranov, V.N. Koptelov, R.Sh. Nazmutdinov and E.I. Pospelova, Patent RU 2228310 C2 (10 May 2004).

[19] R.V. Lyutyy, Foundry production 5, 13 (2016).

[20] R.V. Lyutyy, D.V. Keush, V.O. Naboka, A.R. Pyvoshchuk, Bulletin of the Donbass State Engineering Academy 1(37), 55 (2016).

[21] R.V. Lyutyy, D.V. Keush, Foundry production 4, 23 (2017).

[22] R.V. Liutyi, M.V. Tyshkovets, D.V. Liuta, Physics and Chemistry of Solid State. 21(1), 176 (2020) (https://doi.org/10.15330/pcss.21.1.176-184).

[23] J. Kingery, Introduction to ceramics (Moscow, Izdatel'stvo literatury po stroitel'stvu, 1967).

[24] R.V. Lyutyy, I.M. Guriya, D.V. Keush, V.S. Smol'skaya, Foundry production 5, 28 (2014). 
[25] B. Lorent, M. Szeplaki, Thermogravimetrische und thermoanalytische Untersuchungen kondensierden Phosphate 11, 357 (1967).

[26] N.M. Dombrovskiy, J. Sci. Chem. 5(8), 1699 (1960).

[27] R.A. Lidin et al., Chemical properties of inorganic substances: Textbook for universities (Moscow, Khimiya, 2000) (ISBN 5-7245-1163-0).

[28] N.M. Dombrovskiy, J. Sci. Chem. 7(1), 104 (1962).

[29] Web source: https://www.chemical.com.ua.

[30] Web source: http://www.chemport.ru.

[31] S.I. Berul', N.K. Voskresenskaya, J. Sci. Chem. 10(5), 1110 (1965).

[32] P.N. Fedorov, M.V. Mekhoseev, V.N. Krivenko, J. Sci. Chem. 7(1), 76 (1962).

[33] N.M. Smirnova, N.I. Silant'eva, R.G. Lepilina et al., Research in the production of phosphorus and its compounds 27, 74 (1977).

\section{Р.В. Лютий, М.В. Тишковець, Д.В. Люта, О.І. Шейко \\ Фізико-хімічні основи використання фосфатів натрію у ливарному виробництві}

Національний технічний університет Украӥни «Київський політехнічний інститут імені Ігоря Сікорського», Kuїв, Україна, rvl2005@ukr.net, maria15021996@gmail.com

Розроблено технологію синтезу неорганічного зв'язувального матеріалу на основі триполіфосфату натрію $\mathrm{Na}_{5} \mathrm{P}_{3} \mathrm{O}_{10}$ та ортофосфорної кислоти. Технологія передбачає попереднє змішування вказаних компонентів 3 подальшою витримкою в температурному інтервалі $150 \ldots 200{ }^{\circ} \mathrm{C}$. Установлено послідовність здійснення фізико-хімічних перетворень у цій системі, а також оптимальне масове співвідношення ортофосфорної кислоти та триполіфосфату натрію.

У дослідженнях застосовано методи кількісного та якісного рентгенофазового аналізу, диференційного термічного аналізу, стандартні способи випробування зразків на міцність при стисканні. Фазовим аналізом виявлено, що отриманий в результаті хімічного синтезу матеріал являє собою переважно пірофосфат натрію $\mathrm{Na}_{2} \mathrm{H}_{2} \mathrm{P}_{2} \mathrm{O}_{7}$, який має ряд цінних властивостей для застосування у технологіях виготовлення ливарних форм і стрижнів. Співвідношення атомних радіусів катіона (Na) та аніона $\left(\mathrm{P}_{2} \mathrm{O}_{7}\right)$, а також наявність водневих зв'язків забезпечують значне підвищення зв'язувального потенціалу порівняно з іншими фосфатами натрію.

Установлено, що зміцнення сумішей з $2 \ldots 8$ мас. ч. пірофосфату натрію, наповнювачем у яких $\epsilon$ пісок на основі кварцу, максимально інтенсивно відбувається при нагріванні до $150{ }^{\circ} \mathrm{C}$. Подальше підвищення температури понад $250^{\circ} \mathrm{C}$ призводить до перетворення пірофосфату натрію на звичайний (неполімерний) метафосфат $\mathrm{NaPO}_{3}$, який існує без змін хімічної будови до $1000{ }^{\circ} \mathrm{C}$. Ливарні форми і стрижні із розробленим зв'язувальним матеріалом мають належну термічну і хімічну стійкість до розплавів сталі та чавуну, що доведено експериментально.

Розроблений зв'язувальний матеріал, 3 огляду на світові тенденції декарбонізації та ресурсозбереження, являється конкурентною альтернативою до широко застосовуваних синтетичних смол та інших органічних матеріалів. Він не містить шкідливих речовин та не виділяє небезпечних продуктів під час нагрівання.

Ключові слова: зв'язувальний матеріал, іонний радіус, міцність при стисканні, ортофосфорна кислота, пірофосфат натрію, стрижнева суміш, триполіфосфат натрію. 